\title{
Adaptation to the Bologna Process: The Case of Turkey
}

\author{
Verda Gizem Furuzan ${ }^{\mathrm{a}, *}$ \\ ${ }^{a}$ Marmara University School of Foreign Languages, Istanbul, Turkey
}

\begin{abstract}
The Bologna Declaration of 19 June 1999 was signed by 29 ministers responsible from higher education in their countries. The explicit purposes of the Bologna Process were to increase the comparability and readability of degrees across all member state higher education systems. The aim of the Bologna Process is to have a common bachelor's-master's-doctorate system in all of European Union member countries. The Bologna Process is the process of creating the European Higher Education Area and is based on cooperation between ministries, higher education institutions, students and staff from 47 countries, with the participation of international organizations. It has been a major reform initiative in the last two decades. This article describes with the dynamics of Bologna Process and the European Union's growth and jobs strategy. It concentrates on the origins and applicability of the Bologna Process. Further, it reviews the applications and implementation of the Bologna Process in the Turkish higher education system. Besides, its effects to Turkish higher education sector are discussed.
\end{abstract}

\begin{abstract}
Abstrak
Deklarasi Bologna 19 Juni 1999 ditandatangani oleh 29 menteri yang menangani pendidikan tinggi di negara masing-masing. Tujuan utama dari proses Bologna adalah meningkatkan kesetaraan dan keterbacaan gelar akademik dalam sistem pendidikan tinggi di semua negara anggota. Tujuan dari proses Bologna adalah untuk mencapai kesetaraan sistem gelar Sarjana S.1-Master-Doktor di semua negara anggota Eropa Serikat. Proses Bologna adalah upaya mengembangkan Pendidikan Tinggi di Eropa dan didasarkan atas kerjasama antar kementerian, institusi pendidikan tinggi, mahasiswa dan staf dari 47 negara, dengan partisipasi berbagai organisasi internasional. Program ini menjadi kebijakan reformasi besar dalam dua dekade terakhir. Artikel ini dimulai dengan dinamisasi Proses Bologna dan strategi kerja dan pertumbuhan Uni Eropa. Tulisan ini juga membahasa asal usul dan aplikasi Proses Bologna. Kami akan menganalisa aplikasi dan implementasi Proses Bologna pada sistem pendidikan tinggi di Turki, dan juga dampaknya terhadap sektor pendidikan tinggi Turki.
\end{abstract}

Keywords: Bologna Process, Higher Education, Turkey

\section{Introduction}

From 1999 many studies and analyses have been made and published about the Bologna Process. According to all these publications, the Bologna Process has been acknowledged as the deepest and most far reaching higher education reform process since World War II. Besides, in many publications the lack of proper data, growing complexity of the process, its contradictions and tensions are also mentioned (Kehm 2010). It is often mentioned that the Bologna Process bares a paradigm change in European higher education. This change has roots from a number of

*Corresponding author. Marmara University School of Foreign Languages, Goztepe Campus 34722 Kadikoy, Istanbul, Turkey. Email: gizem@marmara.edu.tr. national, continental traditions of higher models. This new tradition resembles the Anglo-American system, because it differs significantly from either American or British traditions. Thus, the harmonization happens as a result of being closed to the traditions. According to European Law, harmonization means the approximation of national laws in order to create one European standard. The Bologna Process provides the harmonization and standardization of higher education systems. In this system, undergraduate studies are followed by graduate studies, and the degrees comparable among different nations (Garben 2010a; Kurelic 2009).

The research questions of the present study are: (a) What are the dynamics of Bologna Process and the European Union?; (b) How can we apply and implement the Bologna Process to the Turkish higher education system.” Besides, in this study I will dis- 
cuss the effects of the Bologna Process on the Turkish higher education subsector.

There are two main dimensions of the Bologna Process. One of them is social dimension, where developing national action plans were monitored and the other dimension is developing new strategies for the global dimension of European higher education. As it was declared, the most important aim of the Bologna Process is to create a European Higher Education Area (EHEA) (Bologna Declaration 1999). According to European Law, harmonization means the approximation of national laws in order to create one European standard. The Bologna Process provides the harmonization and standardization of higher education systems (Garben 2010a).

Bologna Declaration of 19 June 1999 was signed by 29 ministers responsible from higher education in their countries. Actually, The Bologna Process officially started with the Sorbonne declaration of 25 May 1998. But the Bologna Declaration gave its name to the process. Since Sorbonne had the original four participants of signatories, Bologna Declaration had a larger number of signatories (Hoareau 2012; Voegtle et al. 2011). As a consequence of the Bologna Process, the European Higher Education Systems have been subjected to an unprecedented amount of reforms that have been taking place over the last decade. The explicit purposes of the Bologna Process were to increase the comparability and readability of degrees across all member state higher education systems (Dale 2007). The aim of the Bologna Process is to have a common bachelor's-master's-doctorate system in all European Union (EU) member countries. By May 2005, with the inclusion of Armenia, Azerbaijan, Georgia, Moldova, and Ukraine, 45 countries signed the Bologna Process. By this way, the number of employed European citizens increased and also Europe can compete more effectively in the international area. Besides the Bologna Process, Lisbon Strategy, and Bergen Declaration affect higher education policies as their goals are to establish the world's most competitive knowledge economy (Garben 2010b). In Bergen, the ministers responsible for higher education in their countries met and discussed the mid-term achievements of the Bologna Process; the adaption of the Standards and Guidelines for Quality Assurance in the EHEA was also discussed (Toma-Bianov and Craciun 2010).

To create EHEA, an easily readable and comparable degree of the system should be established. First a two- after that a three-tier system and a credit transfer system has been started to be used by many higher education institutions (HEIs). Academic mobility and European cooperation in quality assurance were the key elements that have been applied to enable creation of these degree cycles in a transparent and harmonious manner. Among the central features of the Bologna Process are a re-definition of the curricula, a student-centered learning, the definition of learning-outcomes, the development of competencies, and the implementation of a two- tier system, where the first cycle (bachelor's) is followed by a one year and a half or two-year second cycle (master's) (European Ministers of Education 1999). The Bologna Process helped countries achieve a common degree architecture $(3+2+3)$, a European Credit Transfer System (ECTS), and the beginning of a quality assurance system. In another words, the degree awarded after the first cycle shall also be relevant to the European labor market as an appropriate level of qualification. In most European countries, the second cycle leads to a master's or doctorate degree (Garben 2010a). The two-tier system enhances flexibility for students entering the labor market after the end of the first cycle and enables them to eventually return to the higher education system to enroll in a master's degree-level studies which often better fits their interests (Portela et al. 2009). Many tools have been developed or adapted in higher education systems for the development of the Bologna Process at an institutional and country level (Voegtle et al. 2011). The European Research Area (ERA) emphasizes the importance of research as an integral part of higher education across Europe. ERA also points out that beyond the present focus on two main cycles of higher education, the doctoral level should be accepted as the third cycle of higher education. They remark the importance of research and research training and the quality and competitiveness of European higher education.

At the beginning of this century, like in many other countries, the Turkish higher education system was affected by many elements: (1) demands of students to higher education and establishments of new universities, (2) the beginning of the interaction and cooperation of Eastern and Central Europe and the rest of the continent, (3) an increase in competition and cooperation in higher education at a global level (Lucin and Samarzija 2011).

This article concentrates on the origins and applicability of the Bologna Process. It also looks at the concept of European integration and the results of implementing integration initiatives in Turkey. The study also reviews the applications and implementation of the Bologna Process in Turkish higher education system. In addition, the Bologna Process's effects to the Turkish higher education sector will be discussed.

The Bologna Process includes a definition of Europe which was developed by the Council of Europe (CoE). Because of this reason the process is not limited to EU-member countries. Like Turkey, there are many countries where the Bologna Process applies yet not the member of EU. The candidacy for EU membership of Turkey continued with ups and downs. During the Bologna Process initiating processes, ministers of education who helped initiate the Bologna Process involved non-governmental organizations (NGOs), in particular those representing universities and students, but not those representing university staff. These organizations together with the Commission were incorporated into a fol- 
low up organization which is called the Bologna Follow-Up Group (BFUG). This group is composed of Bologna representatives from the signatory states and representatives of the Commission and the advising bodies (Voegtle et al. 2011). BFUG is the authorized decision-making body between biannual ministerial conferences, and meets at least twice a year. The aim of this meeting is the preparation of the following year's ministerial summit, adoption of the Bologna Process work plan, election of the BFUG board and creation of working groups, among other (Lazetic 2010). Figure 1 illustrates actors and the goals of Bologna Process.

\begin{tabular}{|c|c|c|c|c|c|c|}
\hline Signatory & Signatory & Signatory & Signatory & Signatory & Signatory & Signatory \\
\hline \multirow[t]{4}{*}{ States (4) } & States (29) & States (32) & States (32) & States (45) & States (45) & States (45) \\
\hline & & Commission & Commission & Commission & & \\
\hline & & $\begin{array}{l}\text { BFUG (+EUA, EU- } \\
\text { RASHE, CoE, ESIB) }\end{array}$ & $\begin{array}{l}\text { BFUG (+EUA, EU- } \\
\text { RASHE, CoE, ESIB) }\end{array}$ & $\begin{array}{l}\text { BFUG (+EUA, } \\
\text { EURASHE, CoE, } \\
\text { ESIB, EI, ENQA, } \\
\text { Business Europe) }\end{array}$ & $\begin{array}{l}\text { BFUG (+EUA, } \\
\text { EURASHE, CoE, } \\
\text { ESIB, EI, ENQA, } \\
\text { Business Europe) }\end{array}$ & $\begin{array}{l}\text { BFUG (+EUA, } \\
\text { EURASHE, CoE, } \\
\text { ESIB, EI, ENQA, } \\
\text { Business Europe) }\end{array}$ \\
\hline & & & Secretariat & Secretariat & Secretariat & $\begin{array}{l}\text { Secretariat } \\
\text { (co-chaired by EU- } \\
\text { Presidency and } \\
\text { non-EU country) }\end{array}$ \\
\hline 1998 & 1999 & 2001 & 2003 & 2005 & 2007 & 2009 \\
\hline Sorbonne & Bologna & Prague & Berlin & Bergen & London & Benelux \\
\hline Declaration & Declaration & Communiqué & Communiqué & Communiqué & Communiqué & Communiqué \\
\hline \multirow[t]{9}{*}{$\begin{array}{l}\text { Common Framework } \\
\text { for Qualifications }\end{array}$} & $\begin{array}{l}\text { Common Framework } \\
\text { for Qualifications }\end{array}$ & $\begin{array}{l}\text { Common Framework } \\
\text { for Qualifications }\end{array}$ & $\begin{array}{l}\text { Common Framework } \\
\text { for Qualifications }\end{array}$ & $\begin{array}{l}\text { Common Framework } \\
\text { for Qualifications }\end{array}$ & $\begin{array}{l}\text { Common Framework } \\
\text { for Qualifications }\end{array}$ & $\begin{array}{l}\text { Common Framework } \\
\text { for Qualifications }\end{array}$ \\
\hline & $\begin{array}{l}\text { Creation of EHEA } \\
\text { by } 2010\end{array}$ & $\begin{array}{l}\text { Creation of EHEA } \\
\text { by } 2010\end{array}$ & $\begin{array}{l}\text { Creation of EHEA } \\
\text { by } 2010\end{array}$ & $\begin{array}{l}\text { Creation of EHEA } \\
\text { by } 2010\end{array}$ & $\begin{array}{l}\text { Creation of EHEA } \\
\text { by } 2010\end{array}$ & $\begin{array}{l}\text { Creation of EHEA } \\
\text { by } 2010\end{array}$ \\
\hline & Diploma Supplement & Diploma Supplement & Diploma Supplement & Diploma Supplement & Diploma Supplement & Diploma Supplement \\
\hline & Two-cycle system & Two-cycle system & Two-cycle system & Two-cycle system & Two-cycle system & Two-cycle system \\
\hline & $\begin{array}{l}\text { Credit Transfer Sys- } \\
\text { tem }\end{array}$ & $\begin{array}{l}\text { Credit Transfer Sys- } \\
\text { tem }\end{array}$ & $\begin{array}{l}\text { Credit Transfer Sys- } \\
\text { tem }\end{array}$ & $\begin{array}{l}\text { Credit Transfer Sys- } \\
\text { tem }\end{array}$ & $\begin{array}{l}\text { Credit Transfer Sys- } \\
\text { tem }\end{array}$ & $\begin{array}{l}\text { Credit Transfer Sys- } \\
\text { tem }\end{array}$ \\
\hline & & Life Long learning & Life Long learning & Life Long learning & Life Long learning & Life Long learning \\
\hline & & & Quality Assurance & Quality Assurance & Quality Assurance & Quality Assurance \\
\hline & & & $\begin{array}{l}\text { Three Cycle System } \\
\text { (including doctoral } \\
\text { level) }\end{array}$ & $\begin{array}{l}\text { Three Cycle System } \\
\text { (including doctoral } \\
\text { level) }\end{array}$ & $\begin{array}{l}\text { Three Cycle System } \\
\text { (including doctoral } \\
\text { level) }\end{array}$ & $\begin{array}{l}\text { Three Cycle System } \\
\text { (including doctoral } \\
\text { level) }\end{array}$ \\
\hline & & & & $\begin{array}{l}\text { Standards and guide- } \\
\text { lines for Quality } \\
\text { Assurance }\end{array}$ & $\begin{array}{l}\text { Standards and guide- } \\
\text { lines for Quality } \\
\text { Assurance }\end{array}$ & $\begin{array}{l}\text { Standards and guide- } \\
\text { lines for Quality } \\
\text { Assurance }\end{array}$ \\
\hline
\end{tabular}

Figure 1. Actors and the Goals of Bologna Process

Source: Voegtle and colleagues (2011). 
The most important NGOs are the European University Association (formerly CRE, renamed EUA), the European Association of Institutions in Higher Education (EURASHE), and the European Students' Union (former ESIB, renamed as ESU in 2007) (Reinalda 2008). The fields of cooperation have been enhanced with Prag (2001), Berlin (2003), Bergen (2005), London (2007), Benelux (2009) and Budapest/Wien (2010) Declarations afterwards (see Figure 1). Main fields of cooperation under Bologna Process are as follow:

- Recognition of diplomas and education terms

- Life Long Learning Program (LLP)

- Mobility

- Employability

- Quality Assurance

- Student-Oriented Learning

- Research and Innovation

- Social dimension in education

- Common degrees

- A comparable and clear cut academic degree system

Accreditation is a component of the Bologna Process's quality assurance policy. Ministries of education are the actors and the targets of the process. They plan the objectives on the European level and are committed to implement them on the national level. The accreditation makes European higher education policies more applicable in ways that were impossible in 1990s. Accreditation is an interesting question in the context of quality assurance and it provides the Bologna Process to be applicable to the national quality assurance systems (Saarinen and Ala-Havala 2007).

\section{Methods}

This study was conceptualized using a non-experimental, descriptive research method, namely archival/document analysis. This research method is used to analyze trends across time, and generally, to describe what exists, in what amount, and in what context (Isaac and Michael 1997). The data were collected from the Student Selection and Placement Center (ÖSYM) statistics of Turkey, Turkish Council of Higher Education (YÖK) reports, and the Bologna Declaration reports.

\section{Higher Education System of Turkey and the Bologna Process}

The Turkish higher education system has a centralized structure. All universities (both state and private, or in a true sense, foundation universities) are subject to the Higher Education Law
(No. 2547) and regulations/rules. They have the responsibility of planning, coordination and supervision of higher education. As it is mentioned above Turkish higher education system is mainly composed of universities. It has a unitary system consisting of only universities; short cycle vocational programs are offered by universities. At the institutional level as a university, Rector has all of the responsibilities of financial, academic and administrative control. At the faculty level of a university, the Dean has all of the responsibilities that are similar to the ones of the Rector. In Turkey there are two types of universities; state universities and foundation universities which are private and non-profit types of universities (Council of Higher Education 2003).

For more than two decades Turkish higher education system has gone into a serious re-structuring and development processes. In 1981 there were only 19 state universities, but this number rose to 51 in 1992 (Şenses 2007) and today there are 171 universities and academies in Turkey. Some 103 of them are state universities (five of which are institutes of technology, and one of which is a fine arts university), and 75 private foundation universities (seven of which are two-year institutions), four military academies, and one police academy. Turkey signed the Bologna Declaration in 2001. But it is not yet an EU-member country.

According to restructuring needs of the Turkish education system, in 2001, Turkey participated to Bologna Process and it is turned into an official process for the country. The Council of Higher Education (YÖK) is the primary institution responsible from the implementation of Bologna Process in Turkey. The Bologna Process provides students, academicians, and all other stakeholders' greater compatibility and comparability in the many European systems of higher education.

A series of reforms have been introduced in Turkish HEIs since becoming a Bologna Process signatory country in 2001. After becoming a signatory country, Turkish HEIs can be analyzed in terms of their degree structures, student mobility, lifelong learning programs, quality assurance initiatives, and also the social dimension influenced by the Bologna Process. In the last 20 years the new developments in higher education in Turkey have been made in accordance with the Bologna reforms (Yağc1 2010).

In Turkey, all HEIs use a similar credit system with that of North American universities. The credit system consists of the weekly theoretical course hours and the weekly laboratory, practical, or studio course hours. In addition, each course is allotted a predetermined number of credit hours. ECTS is one of the most important areas of investigations in the application phase of Bologna Process in Turkey. In recent years, many universities in Turkey intensified their efforts in adjusting their credit and grading systems to ECTS principles (Council of Higher Education 2003). The Diploma Supplement and ECTS became mandatory 
implementations at all HEIs from the end of the 2005-2006 academic year. Socrates/Erasmus required a stricter application of ECTS principles. In 2003, 15 universities were selected for the pilot project of Socrates/Erasmus student mobility and ECTS/DS studies. Today, all HEIs have been given special consideration to Erasmus student mobility program and also ECTS credit systems.

There was no accreditation system in Turkish higher education until recently. Universities were only officially and centrally recognized by YÖK. Since 2003, all higher education degree programs have been evaluated by the Commission of Academic Assessment and Quality Improvement in Higher Education (YODEK). This Commission examines the academic assessment reports on the basis of the program to the Council of Higher Education and the Inter-University Council (UAK). The general purpose of quality assessment in Turkey was a combination of accountability, improvement, information sharing, and accreditation. Besides, the Turkish education system is grounded on the convergence of the reflective principles of self-evaluation, peer review, performance measures, and published reports (Bologna Declaration 2005).

The YÖK, the Turkish University Rectors' Committee (TURC), and the UAK are involved in the Bologna Process as stakeholders. The independent Commission for Academic Assessment and Quality Improvement in Higher Education (YODEK) was established in accordance with the above-mentioned regulation by the CoHE in 2005. In this commission nine members are elected by UAK and one student member appointed by the national student union. The Guide on Academic Assessment and Quality Improvement in HEIs are in line with the Standards and Guidelines for Quality Assurance in EHEA that was published by YODEK. According to the goals and objectives of CoHE, YODEK determines the procedures for the assessment and improvement of academic and administrative services of HEIs.

As in the other European candidate countries participating in the European Union education and youth programs, a National Team (National Agency) of 12 Bologna Promoters was established in 2004. The Team is responsible for the implementation and understanding of the Bologna Process in Turkey. At the beginning of 1990s, some of the leading universities' like Middle East Technical University, Boğaziçi University and Istanbul Technical University, engineering programs were evaluated by Accreditation Board for Engineering and Technology-USA (ABET). After that, more higher education institutes followed these leading universities. During the accreditation evaluation meetings of engineering faculty deans, they established a national accreditation system of engineering programs (MÜDEK), which is similar to ABET 2000 and also it is a partner in EUR-ACE (European Accreditation Programme for Engineering, an ongoing So- crates programme) (Council of Higher Education 2005). They were substantially equivalent of the accredited engineering programs in the United States.

Turkish higher education has a two-tiered structure system except for Dentistry, Medicine, and Veterinary Medicine programs, which have a one-tier system, one of which is an undergraduate program and the others are considered graduate-level studies. The duration of Dentistry and Veterinary Medicine programs is five years and that of Medicine programs is six years. The qualifications in these three fields of studies are equivalent to the traditional bachelor's plus master's degree. Undergraduate-level programs consist of two year Associate's degree and four year bachelor's degree programs. Graduate-level programs are composed of master's (MA, MS, and MBA, etc.) and doctorate ( $\mathrm{PhD}$ ) degrees. In addition, there are two kinds of master's programs; one requires a thesis and the other does not require thesis. If a student chooses a master's program without a thesis, this student in ineligible to apply to the country's PhD programs (Council of Higher Education 2003; 2005). The number of students in the first (including the associate degree) and second cycles has doubled in 2000-2001 to 2008-2009. These figures correspond to an increase in the gross enrollment ratio from 23.5 percent to 45.8 percent (ÖSYM 2010).

\section{Results}

Although the Bologna Declaration had been the subject of discussions in academia and among professional bodies, there have been significant changes in the Turkish higher education system inspired by the main tenants of the Bologna Process. The adaption of the two-tier system initiated the process of substantial reforms in many Turkish HEIs. It helps Turkish HEIs to gain momentum. Degree recognition, quality assurance, qualification framework, and a new accreditation system have been the major themes of the Bologna Process reform initiatives in Turkey. However, when the qualification framework, learning outcomes and ECTS applications of Turkey, especially, at the international levels are compared, it can be stated that there is not enough integration at the national level. As Lucin and Samarzija (2011) note there remain two main challenges in order for Turkey to realize the full implementation of ECTS: measuring credits in terms of student workload and linking them with learning outcomes.

Since the beginning of the implementation of the Bologna Process, each university in Turkey has been preparing its annual strategic plan according to the Law on Public Financial Management and Control (No. 5018), which was enacted on 1 January 2007. In addition to the efforts made with ABET for external accreditation and evaluation, some external national quality assurance agencies (like MÜDEK) have started to operate. 
A Draft Report on the Strategy for Higher Education to 2025 was prepared by the Strategy Development Commission formed by the CoHE at the end of 2006. In order to obtain support for developing policy proposals for the implementation of the Bologna Process, the Bologna Coordination Commission (BEK) will be established in all HEIs in Turkey (Bologna Process 2008). As is noted above, the two-cycle degree structure has been fully implemented through the Turkish higher education system. About 97 percent of all students are enrolled in the two-cycle degree system in 2008-2009.

Third-cycle programs are all structured in Turkey by the graduate schools affiliated to the universities. The total number of doctoral candidates for the academic year 2007-2008 was 34,879, which comprised approximately 1.8 percent of all students (excluding students from vocational higher schools, which are in the short-cycle system). In the Turkish higher education system, thirdcycle students are considered doctoral students. According to 2007 statistics of Thomson's ISI Web of Science index, Turkey is 19th in the World Ranking according to publications in scientific journals. Moreover, the scientific publications of Turkey have increased from 15,347 to 21,273 between 2005 and 2007.

\section{Conclusion}

This article introduced the influence the Bologna Process has had on Turkish higher education over the past decade. The Bologna Process can be conceptualized as a process of transnational communication between Turkey and most of its European neighbor countries. The results of this study suggest that the implementation of the Bologna Declaration has brought significant changes in the Turkish higher education system. The Turkish higher education system has benefited from these changes and reform processes of the Bologna Process.

One of the most important points that can be made from this study is that due to the Bologna Process, administrators and managers of Turkish HEIs are successfully developing third-cycle, doctorate-level programs. This cycle creates more insistent pressure on the need of ECTS/DS. In addition, quality assurance, degree recognition, qualification framework, and a new accreditation system have been the major achievements of this reform process. However, even with all these achievements, there is still not enough integration at the national level between the qualification framework, learning outcomes, and ECTS.

Undoubtedly, the Turkish higher education system has been dramatically transformed after the application of the Bologna Process since 2001. In many ways the Bologna Process has served as the catalyst in helping the Turkish higher education system progress toward a more modern system. The reformation process that is currently underway should contribute to the attractiveness and competitiveness of the national education system in the international market for educational services. The Bologna Process can be seen as a possibility to rethink the meaning of internationalization in HEIs in Turkey, even though it has not been considered the only promoter of such trends for studies and academic work.

This article has analyzed the dynamics of the Bologna Process and its implementation and applications on the Turkish higher education system. The results suggest that the convergence process of higher education in Turkey continues to make progress. Two aspects have contributed to this evolution. The third cycle of the Bologna Process has been implemented as well. The Turkish higher education sector as a whole will continue to develop its international dimensions as a high priority. Its researchers will continue to operate internationally at the highest possible levels. The effective alignment with the Bologna Process can assist Turkey in reaching its national goals and increase the global attractiveness of the country's HEIs.

\section{References}

Bologna Declaration. 1999. The Bologna Declaration of 19 June 1999. Bologna, Italy: European Commission.

Bologna Process. 2008. Towards to European Higher Education Area Bologna Process: National Report 2007-2009. Istanbul, Turkey: European Higher Education Areas.

Bologna Declaration. 2005. Towards the European Higher Education Area Bologna Process National Reports 2004-2005. Istanbul, Turkey: European Higher Education Area.

Council of Higher Education (YÖK). 2003. Higher Education In Turkey. Implementing the Assumptions of the Bologna Declaration in 2001-2002. Istanbul, Turkey: YÖK.

Council of Higher Education (YÖK). 2005. Towards the European Higher Education Area. Bologna Process National Reports 2004-2005. Istanbul, Turkey: YÖK.

Dale, Roger. 2007. “Changing Meanings of the Europe of Knowledge and Modernizing the University: From Bologna to the New Lisbon.” European Education 39 (4): 27-42.

European Ministers of Education. 1999. The Bologna Declaration. Bologna, Italy. European Commission.

Garben, Sacha, and Maria Margaretha. 2010a. "The Bologna Process: From a European Law Perspective.” European Law Journal 16 (2): 186-210.

Garben, Sacha, and Maria Margaretha. 2010b. “The Bologna Process and the Lisbon Strategy Commercialization of Higher Education through the Back Door?” The Croatian Yearbook of European Law and Policy 6: 209-230. 
Hoareau, Cécile. 2012. "Deliberative Governance in the European Higher Education Area: The Bologna Process as a Case of Alternative Governance Architecture in Europe.” Journal of European Public Policy 19 (4): 530-548.

Isaac, Stephen, and William Michael. 1997. Handbook in Research and Evaluation: A collection of Principles, Methods and Strategies Useful in the Planning, Design, and Evaluation of Studies in Education and the Behavioral Sciences. 3rd ed. San Diego, CA: Educational and Industrial Testing Services.

Kehm, Barbara M. 2010. "The Future of the Bologna Process-The Bologna Process of the Future.” European Journal of Education 45 (4): 529-534.

Kurelic, Zoran. 2009. "How Not to Defend Your Tradition of Higher Education.” Politička Misao 46 (5): 9-20.

Lazetic, Predrag. 2010. "Managing the Bologna Process at the European Level: Institution and Actor Dynamics." European Journal of Education 45 (4): 549-562.

Lucin, Pero, and Snjezana Samarzija. 2011. “The Bologna Process as a Reform Initiative in Higher Education in Croatia.” European Education 43 (3): 26-42.

Student Selection and Placement Center (ÖSYM). 2011. Higher Education Statistics 2000-2001 and 2008-2009: Academic Yearbook. Ankara, Turkey: ÖSYM. Available online at: www.osym.gov.tr/Genel/BelgeGoster.aspx?F6E10F8892433C FFD4AF1EF75F7A79689DAC10DE3DF29AC6.

Portela, Miguel, Fernando Alexandre Carla Sa, and Ana Rute Cardoso. 2009. "Perceptions of the Bologna Process: What Do Students’ Choices Reveal?” Higher Education 58: 465-474.

Reinalda, Bob. 2008. "Teaching and Training the Ongoing Bologna Process and Political Science.” European Political Science 7: 382-393.

Saarinen, Taina, and Timo Ala-Havala. 2007. “Accreditation, The Bologna Process and National Reactions: Accreditation as Concept and Action.” Higher Education in Europe 32 (4): 333345.

Şenses, Fikret. 2007. Uluslararası Gelişmeler Işı̆̆ında Türkiye Yükseköğretim Sistemi: Temel Eğilimler, Sorunlar, Çelişkiler ve Öneriler. [The Turkish Higher Education System In Light of International Developments: Main Trends, Issues, Contradicts and Recommendations]. Working Papers of Middle East Technical University, Ankara, Turkey: Middle East Technical University.

Toma, Bianov A., and N. Craciun. 2010. "The Bologna Process and Its Perspectives." Bulletin of the Transylvania University of Braşov 3 (52): 239-242.

Voegtle, Eva M., Christoph Knill, and Michael Dobbins. 2011. “To What Extent Does Transnational Communication Drive Cross-national Policy Convergence?: The Impact of the Bolog- na Process on Domestic Higher Education Policies.” Higher Education 61: 77-94. 